Historic, archived document

Do not assume content reflects current scientific knowledge, policies, or practices. 
351655 

USDA Forest Service

Research Paper INT-110

December 1971

\section{PRECIPITATION CHARACTERISTICS \\ OF SUMMER STORMS \\ AT HIGH-ELEVATION STATIONS IN UTAH}

Eugene E. Farmer and Joel E. Fletcher

INTERMOUNTAIN FOREST AND RANGE EXPERIMENT STATION

Forest Service

U.S. Department of Agriculture

Ogden, Utah 84401

Robert W. Harris, Director 


\section{THE AUTHORS}

EUGENE E. FARMER, Associate Forest Hydrologist on the Watershed Rehabilitation research work unit at Logan, Utah, joined the staff of the Intermountain Station in 1964. He holds B.S. and M.S. degrees in Forestry from the University of Idaho. He is working toward a Ph. D. degree in Watershed Science from Colorado State University.

JOELE. FLETCHER, Professor of Hydrology, Utah Water Research Laboratory, Utah State University, Logan, was in water research with the U.S. Department of Agriculture in Tucson, Arizona; Gallup, New Mexico; Davis, California; and Boise, Idaho. His principal interests have been rainfall-runoff relations, soils and instrumentation, before coming to Utah. 


\section{CONTENTS}

Page

INTRODUCTION ........................... 1

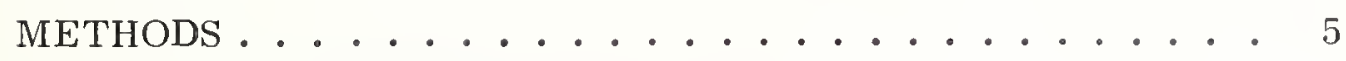

Record Consistency ............ 5

Frequency Analysis .............. 6

Precipitation Zones ............. 6

24-Hour Precipitation Depth . . . . . . . . 6

Average Monthly Depth and Number of Storms . . . . 6

Storm Occurrence by Hour . . . . . . . . 6

Storm Occurrence by Storm Duration ....... 7

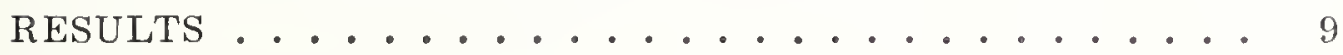

Consistency Test .................. 9

Precipitation Zones ............... 9

Intensity-Duration-Frequency Characteristics . . . . 9

24-Hour Depths. . . . . . . . . . . 14

Monthly Precipitation Depth and Number of Storms. . . 14

Storm Occurrence by Hour. . . . . . . . . 16

Storm Occurrence by Storm Duration . . . . . 18

DISCUSSION . . . . . . . . . . . . 20

LITERATURE CITED ................... 23 


\section{ABSTRACT}

This paper presents the results of data analyses for 25 precipitation intensity stations on two study areas in central and north-central Utah located at elevations between 4,350 and 10,150 feet m.s.l. All data were collected during the period May 1 to October 31. Each station has 10 or more years of record; one station has 30 years of record. The following analyses were made: (1) Record consistency; (2) definition of local precipitation zones; (3) intensity-duration-frequency characteristics; (4) 24-hour depths; (5) monthly depths and number of storms; (6) storm occurrence by hour of the day; and (7) storm occurrence by storm duration. The precipitation zone between 6,500 and 8,000 feet m.s. 1 . is expected to receive the greatest rainfall intensities. There is a trend toward reduced intensities with increasing elevation but the trend is not uniform. However, those precipitation zones that receive the most intense rainfall do not coincide with those zones receiving the greatest depth of rainfall. Generally, rainfall depth increases with elevation, but on one study area the $z$ one that received the greatest depth was not the highest elevation zone. A marked difference in the distribution of storm occurrence by hour between the two study areas is attributed to differences in storm type and to differences in the principal source of summer moisture. Average storm length varies inversely with elevation. 


\section{INTRODUCTION}

Hydrologists commonly accept the fact that rainfall records for high mountain areas are exceedingly scanty. In Utah, most of the rainfall intensity gages are located in the valleys, at elevations less than 6,000 feet m.s.l. Most of the records of rainfall in the valleys have never been analyzed for precipitation characteristics of storms having durations of less than 60 minutes. Even the available records of rainfall in the mountains have never been analyzed for those storm characteristics that are most pertinent to wildland managers and research workers in the field of watershed protection. In fact, most of the available records have never been analyzed beyond weekly or monthly totals.

This paper presents the results of analyses of data from two mountain networks of recording precipitation gages: 11 stations on the Great Basin Experimental Area in central Utah; and 14 stations on the Davis County Experimental Watershed in northern Utah. The gages in central Utah are located at elevations between 5,550 and 10,150 feet m.s.1. The gages in northern Utah are located at elevations between 4,350 and 9,000 feet m.s.1. (figs. 1 and 2).

All of the rainfall records were collected during the period May 1st to October 31st. Most of these records were obtained from weighing-type analog gages, but a few of the earliest records were from tipping-bucket gages. The total records of all stations comprise 495 station seasons; 5,207 station storms were recorded. A single storm was often recorded on more than one gage. 


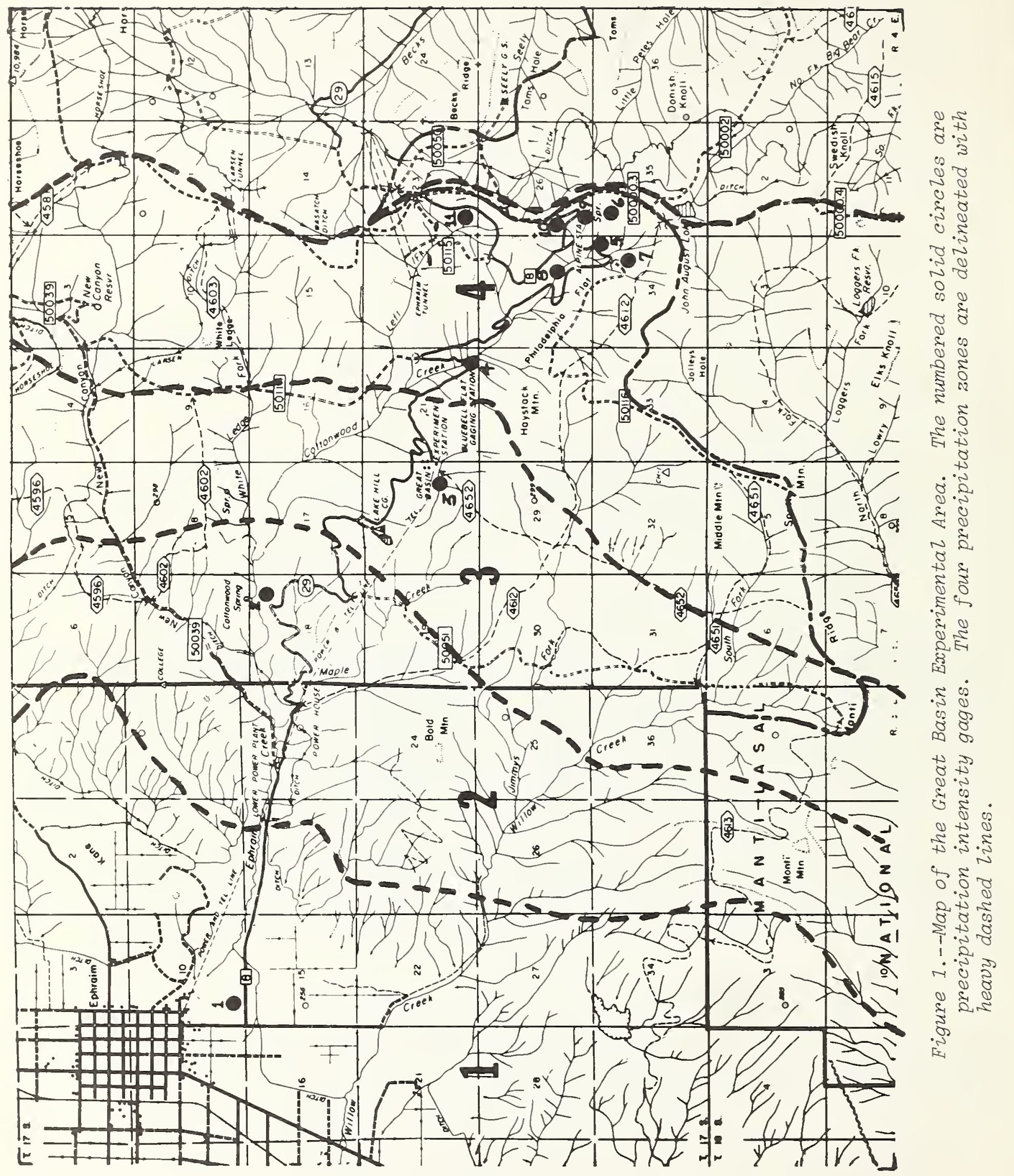




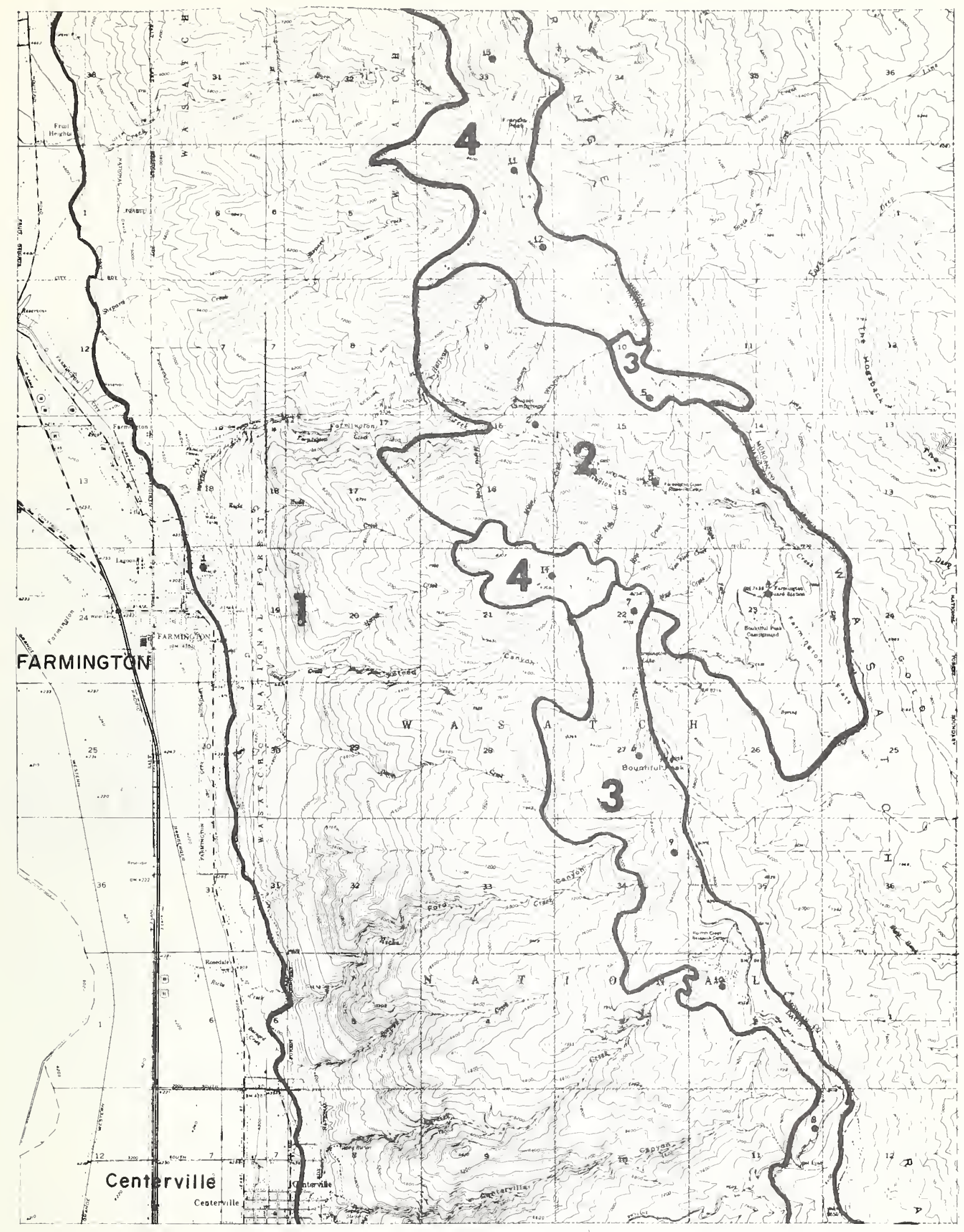

Figure 2.--Map of the Davis County Experimental Watershed. The numbered solid circles are precipitation intensity gages. The four precipitation zones are delineated with heavy solid lines. 
The Davis County Experimental Watershed and the Great Basin Experimental Area are located on the Wasatch Range and the Wasatch Plateau, respectively. These two mountain ranges form the high-elevation midrib of the northern two-thirds of the State of Utah. The Wasatch Range forms the northern half of this midrib and is characterized by steep slopes, deep canyons, and ridges that rise to about 12,500 feet m.s.1.--some 3,000 to 6,000 feet above the adjacent valleys. The high-plateau section of the Colorado Plateau province extends southward from the Wasatch Range to form the southern half of this midrib. The wasatch Plateau extends 75 miles from north to south and has a very narrow summit, usually less than 6 miles wide. The western front is a great monoclinal flexure whose strata bend upward to the summit in a single sweep. The summit is about 10,500 feet m.s.1.--some 4,000 to 5,500 feet above the San Pitch Valley to the west. The rim of the plateau has been notched by erosion and the streams have trenched back toward the summit giving the plateau a dissected appearance.

These two mountain ranges have a relatively long history of land use--particularly grazing--dating back to about 1847. Summer convective storms delivering very highintensity rainfall have been the source of destructive debris floods. Summer debris floods emanating from the Wasatch Range were particularly destructive (Bailey et al. 1934; and Bailey et al. 1947). These summer-flood flows took lives, destroyed property, and disrupted communities.

On both mountain ranges, summer precipitation contributes very little to streamflow. However, it is important to the production of mountain vegetation that is vital to soil stability (Packer 1951; Orr 1957; Packer 1963; and Croft and Bailey 1964). However, vegetal cover is only one factor that affects the hydrologic performance of a watershed. Storm characteristics also have a major effect on the processes of soil erosion and flood production, especially when the land becomes barren of vegetal cover due to fire, road construction, overgrazing, or urban development.

A storm was defined for this study as a period of precipitation, uninterrupted for a period exceeding 1 hour, delivering at least 0.10 inch of water. Most of these storms were convective thunderstorms and frontal thunderstorms aided through orographic lifting. Summer convective cells, often associated with lightning, usually approach from the south or southwest, which is the direction of the prevailing wind of that season. Some of the storms that delivered the greatest intensity of rainfall were probably of a type that has been termed orographic-convective. The primary source of summer moisture aloft comes from the Gulf of Mexico (Humphrey 1962). A small proportion of the total storms comes from large frontal systems. 


\section{METHODS}

Manual and machine methods were used to digitize the original analog rainfall records. Compilation of the digitized record was done by computer. ${ }^{l}$ The final computer output for every storm consisted of both accumulated precipitation depth and rainfall intensity for the following 12 time durations: 2, 5, 10, 15, 20, and 30 minutes and 1 , $2,4,6,12$, and 24 hours. The computer output also included the total precipitation depth for every month as well as a yearly summary of maximum depth and intensity.

\section{Record Consistency}

All of the records were checked for consistency by double-mass plotting (Searcy and Hardison 1960). This technique was applied to the combined depth records only for July and August because all of the gages were in operation during these 2 months. A threestation preliminary base pattern for each study area was arbitrarily selected to which all other stations were compared. From these comparisons, the three most consistent stations were then chosen as the final base pattern.

${ }^{1}$ Appreciation is expressed to Leon Huber and Jack W. Homeyer of Utah State University and the Intermountain Forest and Range Experiment Station, respectively. Mr. Huber is author of the computer program PREINT; Mr. Homeyer authored the computer program ANADIG. These programs contributed materially to the completion of this work. 


\section{Frequency Analysis}

A detailed annual series frequency analysis of rainfall intensity was made for every station. A separate analysis was made for each of the 12 time durations. The formula developed by Weibull was used to obtain plotting positions (Chow 1964).

$$
\mathrm{T}=\frac{\mathrm{n}+1}{\mathrm{~m}}
$$

where

$$
\begin{aligned}
& \mathrm{T}=\text { recurrence interval, years } \\
& \mathrm{n}=\text { number of years of record } \\
& \mathrm{m}=\text { order number of the items arranged in descending order. }
\end{aligned}
$$

This formula has been found to be theoretically suitable for plotting annual maximum series on extremal distribution paper (Chow 1953). However, the data in this study were more nearly straight on extremal log paper.

\section{Precipitation Zones}

Peck and Brown (1962) divided Utah into 20 precipitation regions. They found that a large amount of the variation between regions in the May-September precipitation was accounted for by elevation. All of our data are point data. Consequently, we had to define criteria for dividing the study areas into homogeneous zones in order to make areal application of these point data.

The three criteria used follow: (1) station elevation; (2) the values from the station intensity-duration-frequency curve; and (3) the station $\mathrm{I}_{10} / \mathrm{I}_{2}$ ratio for all durations between 2 and 30 minutes (figs. 1 and 2, tables 1 and 2). The latter is a dimensionless ratio that expresses the average slope of the short-duration rainfall intensity curves between 2 and 10 years. This ratio was computed by dividing the summation of intensities having durations of $2,5,10,15,20$, and 30 minutes for the 10-year recurrence interval by the comparable summation for a recurrence interval of 2 years. Any region that is homogeneous with respect to its rainstorm characteristics should have frequency curves of about equal slope or steepness. Consequently, the $\mathrm{I}_{10} / \mathrm{I}_{2}$ ratio is a useful statistic for comparing the slopes of frequency curves as a basis for judging homogeneity of precipitation zones.

\section{4 - Hour Precipitation Depth}

The intensities for the 24-hour duration were converted to precipitation depths for recurrence intervals of 10,25 , and 50 years. Twenty-four hours was the longest duration examined in this study.

\section{Average Monthly Depth and Number of Storms}

Analyses for the average monthly depth of precipitation and the average number of storms per month are complete only for June-September. At the highest elevation stations, the data for May and October were insufficient to compute a reliable monthly average.

\section{Storm Occurrence by Hour}

Storm occurrence by hour was analyzed by compiling the number of storms starting in any hour of the day expressed as a percent of the total storms. These data were plotted as a mass curve for each zone. 


\section{Storm Occurrence by Storm Duration}

In each zone, 11 duration intervals were established to examine the relationship between storm occurrence and storm duration: 1-10,11-20, 21-30, 31-40, 41-50, 51-60, 61-90, 91-120, 121-240, 241-360, and greater than 360 minutes. The number of storms that occurred in each duration interval was totaled. A mass curve of percent of total storms was plotted against the central value, or "class mark," of each duration interval. These zonal curves are unweighted averages.

Table 1.--Listing of the precipitation intensity stations.

\begin{tabular}{ccccccc}
\hline & $:$ & Map & Zone & Period of $:$ Years of $:$ & Station \\
Station & $:$ & number & $:$ & number & $:$ & record $:$ record $:$ elevation \\
\hline
\end{tabular}

\section{DAVIS COUNTY EXPERIMENTAL WATERSHED}

Farmington Warehouse

Sunset

Rice Climatic Station

Farmington Flat

Head Bigler Creek

Centerville

Parrish Climatic Station

Head Miller Creek

Head Ford Creek

Steed Creek

Bairs Canyon

Head Halfway Creek

Head Sheppard Creek
Mud Creek

$\begin{array}{rl}1 & 1 \\ 2 & 2 \\ 3 & 2 \\ 4 & 2 \\ 5 & 3 \\ 8 & 3 \\ 10 & 3 \\ 14 & 4 \\ 7 & 3 \\ 9 & 3 \\ 6 & 3 \\ 13 & 4 \\ 12 & 4 \\ 11 & 4\end{array}$

GREAT BASIN EXPERIMENTAL AREA

Sorenson's Field

Oaks Climatic Station

GBRS Headquarters

Bluebel1 Bridge

Meadows Climatic Station

Alpine Cattle Pasture

Alpine Physical Factors

Station

Philadelphia Flat

Alpine Area A

Left Fork Ephraim Creek \#1

Alpine Area B

$\begin{array}{rr}1939-68 & 30 \\ 21948-65 & 17 \\ 1942-68 & 27 \\ 1942-65 & 24 \\ 1941-66 & 26 \\ 21948-58 & 10 \\ 1942-63 & 22 \\ 1941-62 & 22 \\ 1939-58 & 20 \\ 1946-62 & 17 \\ 1946-62 & 17 \\ 1947-57 & 11 \\ 1941-66 & 26 \\ 1948-57 & 10\end{array}$

4,350

6,400

6,800

7,600

8,000

8,200

8,200

8,350

8,370

8,700

8,800

8,800

8,900

9,000

$\begin{array}{rrrrr}1 & 1 & 1946-65 & 20 & 5,550 \\ 2 & 2 & 1942-65 & 24 & 7,650 \\ 3 & 3 & 1937-65 & 29 & 8,850 \\ 4 & 4 & 1942-55 & 14 & 9,000 \\ 5 & 4 & 1942-65 & 24 & 9,850 \\ 6 & 4 & 1946-58 & 13 & 9,900 \\ 7 & & & & \\ 8 & 4 & { }^{3} 1919-43 & 20 & 9,900 \\ 9 & 4 & 1942-55 & 14 & 9,950 \\ 11 & 4 & 1944-65 & 22 & 10,100 \\ 10 & 4 & 1946-59 & 14 & 10,100 \\ & 4 & 1944-65 & 22 & 10,150\end{array}$

${ }^{1}$ See figures 1 and 2 .

2 Except 1949.

${ }^{3}$ Except 1921, 1930, 1933, and 1934. 
Table 2.--Precipitation zones for each study area

\begin{tabular}{|c|c|c|c|c|c|c|}
\hline $\begin{array}{c}\text { Precipitation } \\
\text { zone }\end{array}$ & : & $\begin{array}{c}\text { Average station } \\
\text { elevation }\end{array}$ & : & $\begin{array}{l}\text { Zonal } \\
\mathrm{I}_{10 / \mathrm{I}_{2}}\end{array}$ & $:$ & $\begin{array}{c}\text { Vegetal } \\
\text { type }\end{array}$ \\
\hline
\end{tabular}

DAVIS COUNTY EXPERIMENTAL WATERSHED

$\begin{array}{llll}1 & 4,350 & 1.87 & \text { Oakbrush } \\ 2 & 6,930 & 1.94 & \text { Aspen-fir }{ }^{2} \\ 3 & 8,380 & 2.30 & \text { Spruce-fir }{ }^{2} \\ 4 & 8,760 & 2.49 & \text { Spruce-fir }\end{array}$

GREAT BASIN EXPERIMENTAL AREA

\begin{tabular}{llll}
1 & 5,550 & 2.35 & Pinyon-juniper \\
2 & 7,650 & 3.16 & Oakbrush \\
3 & 8,850 & 1.73 & Aspen-fir \\
4 & 9,850 & 2.25 & Spruce-fir \\
\hline
\end{tabular}

${ }^{1}$ The lower limits of this precipitation zone are in the oakbrush type.

${ }^{2}$ The lower limits of this precipitation zone are in the aspen-fir type. 


\section{RESULTS}

\section{Consistency Test}

The records were not adjusted. None of the mass curves plotted as smooth straight lines and isolated points fluctuated both above and below the trend line. Even so, the breaks in the lines didn't persist for a period as long as 5 years. The breaks in the lines were considered to be no greater than might reasonably be expected for thunderstorm data obtained from mountainous areas.

\section{Precipitation Zones}

Within each study area, vegetal patterns were closely related to the four precipitation zones (table 2). This was not unexpected; however, vegetal types were not considered when the precipitation zones were established. On the Wasatch Plateau, the major vegetal types are pinyon-juniper, oakbrush, aspen-fir, and spruce-fir. On the Wasatch Range, the pinyon-juniper type disappears and oakbrush occupies sites similar to those occupied by pinyon-juniper in areas south of the wasatch Range.

\section{Intensity-Duration-Frequency Characteristics}

The curves in figures $3 \mathrm{a}$ to $3 \mathrm{~d}$ and $4 \mathrm{a}$ to $4 \mathrm{~d}$ are for recurrence intervals of 2 to 50 years and storm durations of 2, 5, 10, 20, and 30 minutes and 1, 2, 4, and 6 hours. The 50-year return period intensity is a linear extrapolation and as such must be used with caution. The 10-year intensity is expected to be accurately determined because one or more stations in the eight precipitation zones have records dating back more than 20 years. All of the curves were fitted by eye (Dalrymple 1960). In reading them, it is important to remember that the recurrence interval is the average interval in which an intensity of given duration will recur as an annual seasonal maximum. 
Figure 3.--Intensity-duration-frequency curves for recurrence intervals of 2 to 50 years and durations of 2 minutes to 6 hours for the Davis County Experimental Watershed. Curves for precipitation Zone 1 are shown in $3 a$, Zone 2 in $3 b$, Zone 3 in $3 c$, and Zone 4 in $3 d$. (Log-extreme distribution)
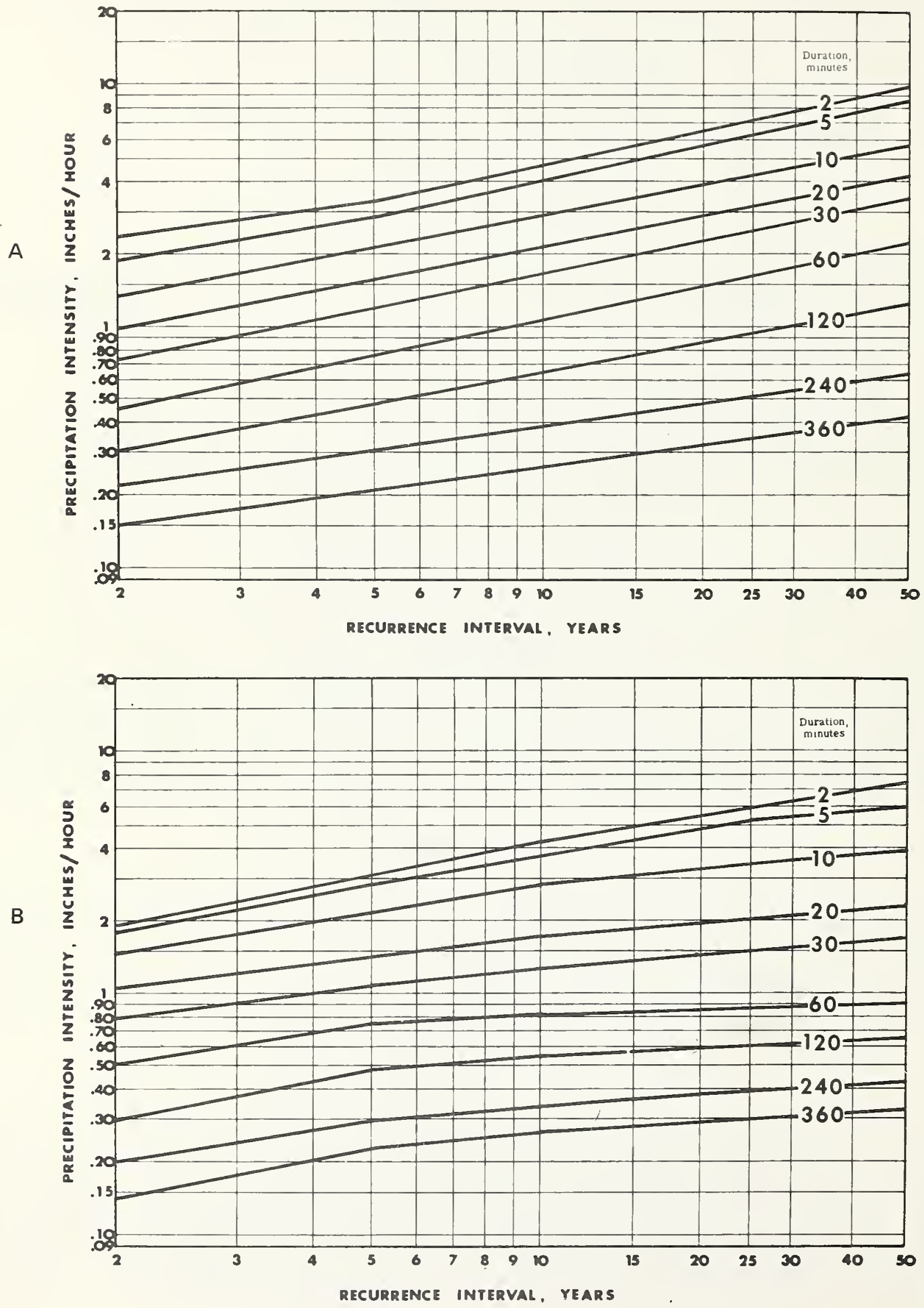

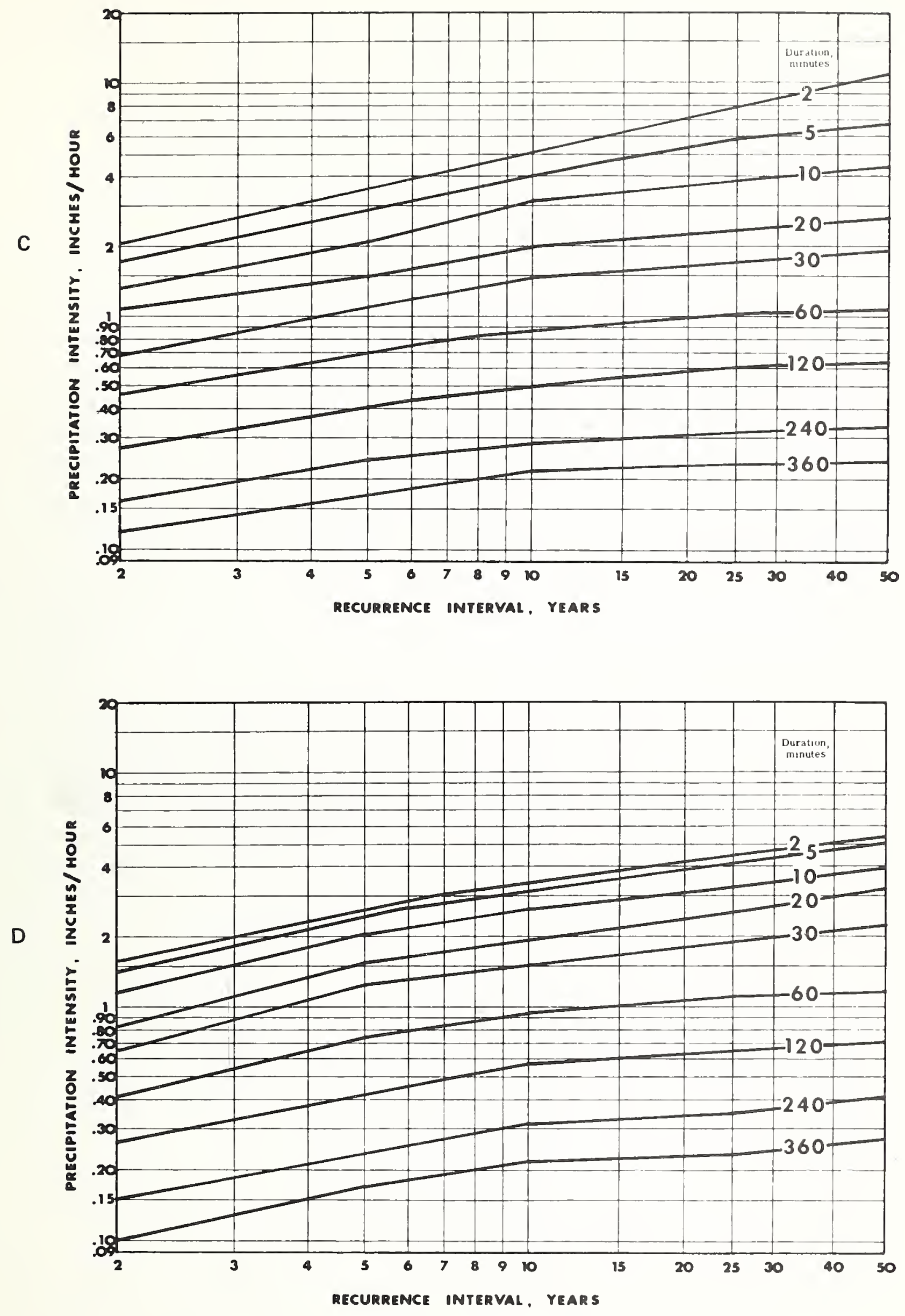
Figure 4.--Intensity-duration-frequency curves for recurrence intervals of 2 to 50 years and durations of 2 minutes to 6 hours for the Great Basin Experimental Area. curves for precipitation Zone 1 are shown in $4 a$, Zone 2 in $4 b$, Zone 3 in $4 c$, and Zone 4 in $4 d$. (Log-extreme distribution)
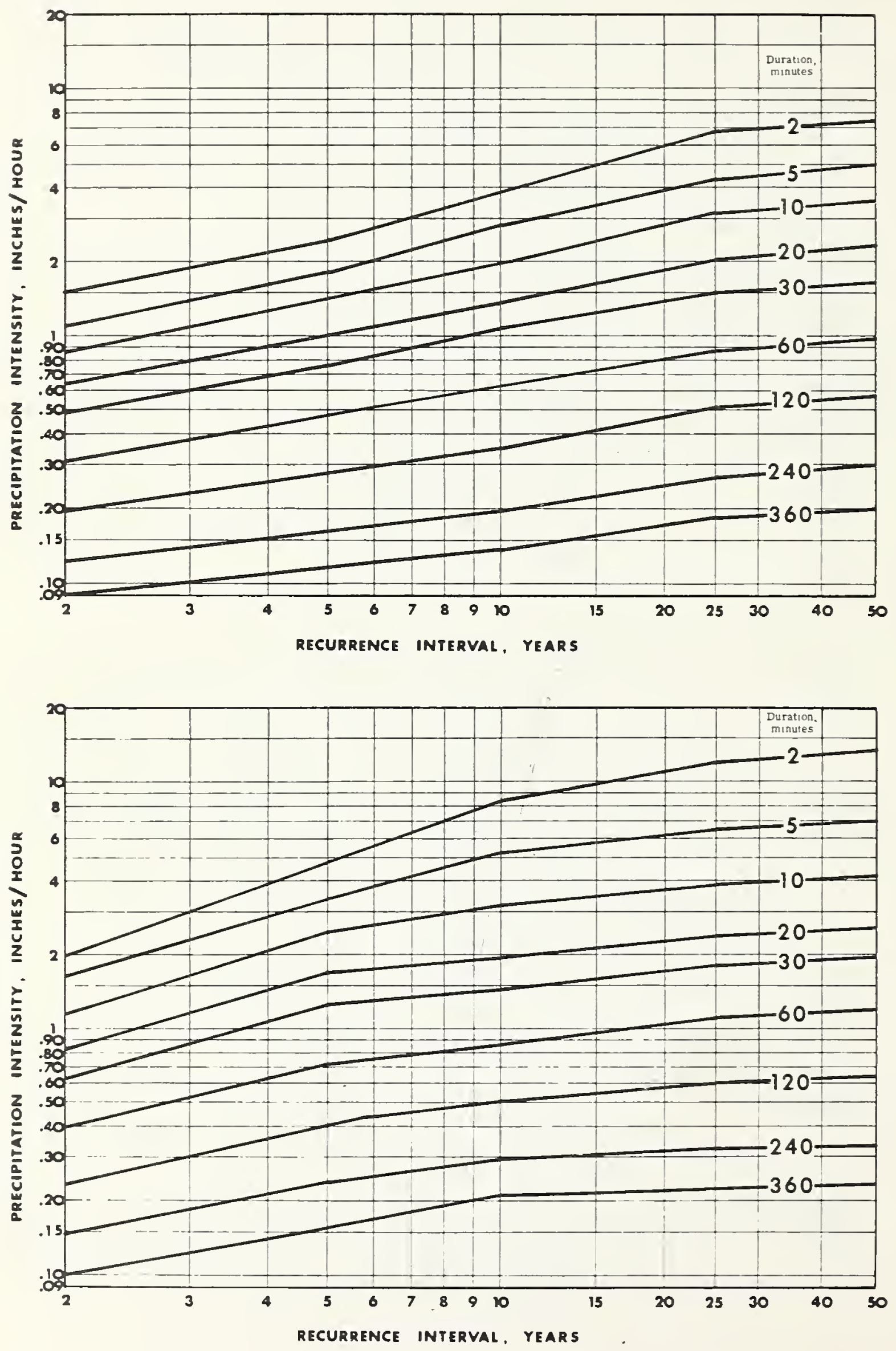

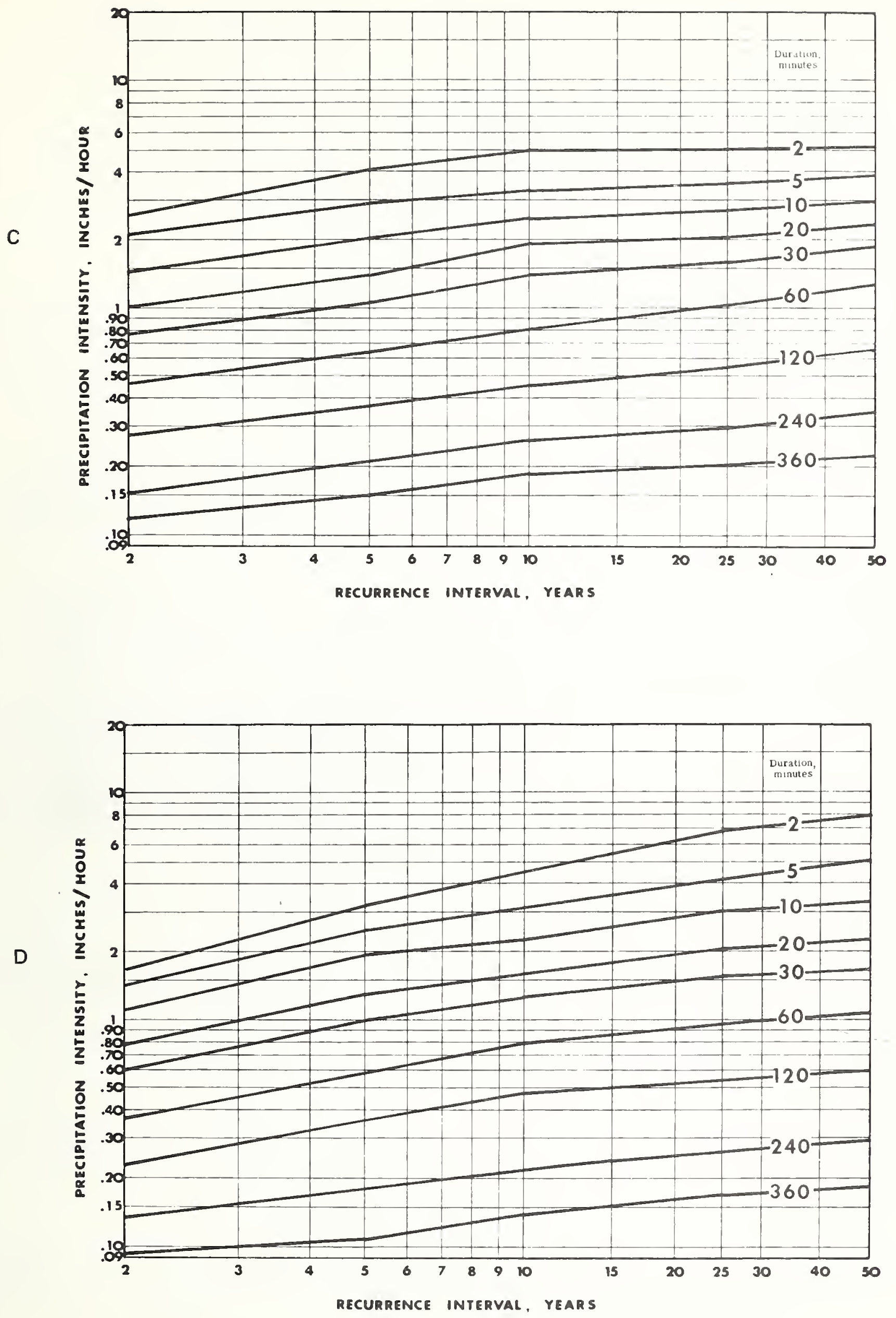
The precipitation values used in making the zonal curves contained some snowfall events. At the higher elevations, snow has been recorded during every month of the year. However, there is little doubt that the values for periods of 2 hours and shorter for recurrence intervals of 10 years and longer are rainfall events.

Close examination of figures 3 and 4 reveals that generalized comparisons are difficult to make. Comparisons should be confined to specific durations and recurrence intervals because the magnitude of the 2-year intensity and the slope of the curves vary within and between zones. For instance, on the Davis County area the expected 20minute, 50-year intensity is greatest in zone 1, while the 20-minute, 2-year intensity is greatest in Zone 3 .

Zone 2, aspen-fir type, in the Davis County area occupies the bottom of the higher reaches of Farmington Canyon. All of this zone lies behind a topographic barrier with respect to the prevailing southwest storm direction, and is the only zone on the leeward slope. The physiographic effect in Zone 2 was not determined precisely; however, compared to Zones 1 and 3, it appears that for durations less than 2 hours the expected intensities decrease--especially at long recurrence intervals.

On both study areas, as elevation increases, there is a trend toward reduced intensities at the longer recurrence intervals. However, this trend is not uniform. On each area maximum expected intensities are usually found in the precipitation zone occupied by the oakbrush type. Fortuitously, this vegetal type also offers good protection against raindrop impact and overland flow.

Expected rainfall intensities in the aspen-fir type on both study areas are somewhat less than those in the oakbrush type at most durations and recurrence intervals, except at the short durations with short recurrence intervals. This exception is probably due to the increased frequency of storm occurrence with increasing elevation. The intensity-duration-frequency curves representative of the higher spruce-fir zone are more steeply inclined than those of the aspen-fir type. In both zones the expected rainfall intensities at short recurrence intervals are about the same, but they are usually greater at the long recurrence intervals in the spruce-fir type. However, the expected intensities in this type are usually less than those in the oakbrush type. On the Davis County Experimental Watershed, Zone 4 in the spruce-fir type is not markedly different from Zone 3 , also in the spruce-fir type, except that the 2 -minute duration values differ only slightly from the 5 -minute values.

\section{4-Hour Depths}

Only a small percentage of storms that occur on either study area have durations greater than 6 hours. However, these storms are of interest in the design of contour trenches and road-drainage devices. Storms of long duration are rarely flood-producing events in these areas. Croft and Marston (1950) indicate that the greatest storms on the Davis County Experimental Watershed averaged much less than 6 hours; they ranged from 30 minutes to $10-1 / 2$ hours.

The intensities were converted to depths because depth 'is of more interest than intensity at the 24-hour duration. The recurrence intervals shown in table 3 are the average intervals in which the given depth will recur as an annual seasonal maximum.

\section{Monthly Precipitation Depth and Number of Storms}

The monthly precipitation depths were determined from gage catch. We hoped that these data could clarify the mountain-valley precipitation relationships when used in conjunction with intensity-duration-frequency characteristics. 
Table 3.--Expected connal seasonal maximum 24-hour precipitation depths, in inches, by recurrence intervals and precipitation zones

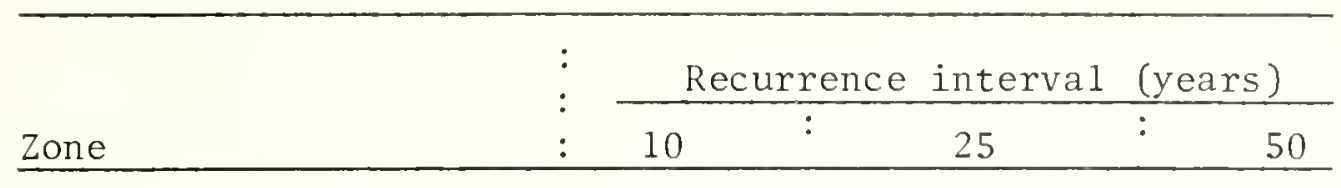

DAVIS COUNTY EXPERIMENTAL WATERSHED

$\begin{array}{llll}1 & 2.21 & 2.54 & 2.74 \\ 2 & 2.04 & 2.38 & 2.45 \\ 3 & 1.44 & 1.87 & 2.11 \\ 4 & 1.54 & 1.87 & 1.97\end{array}$

GREAT BASIN EXPERIMENTAL AREA

\begin{tabular}{llll}
1 & 1.15 & 1.30 & 1.34 \\
2 & 1.49 & 2.16 & 2.47 \\
3 & 1.70 & 2.16 & 2.33 \\
4 & 1.39 & 1.66 & 1.70 \\
\hline
\end{tabular}

Monthly precipitation fluctuates widely between zones and between years. Any month during the period May-October may be completely dry at one or more stations. Also, any month may exceed the average by 300 to 700 percent.

On both study areas, the average number of storms per month tends to vary as does the monthly precipitation depth (table 4). The catch of summer precipitation in Zone 2 on the Davis County Experimental Watershed was relatively high; this was attributed to its leeward position. Hovind (1965) reported similar results, specifically, that gage catch in the lee of a mountain peak exceeded that on the windward slope by as much as 400 percent.

With respect to the zonal intensity-duration-frequency characteristics, the most intense rainfalls do not occur in the precipitation zones receiving the greatest depths of rainfal1. The most intense rainfall is generally expected to occur in Zone 2 on the Great Basin Experimental Area and in Zone 1 of the Davis County Experimental Watershed. The depth of expected rainfall on these zones is less than that on one of the higher elevation zones.

No pronounced dry summer period occurs in the Great Basin area. Price and Evans (1937) found a bimodal dry season in June and September. On the other hand, our analysis shows that July and September are the driest months. Considering the random nature of summer precipitation our results are not in serious conflict with those reported by Price and Evans. On the Davis County Experimental Watershed, July is the driest month, and September is the second driest month. The difference in July totals between the two study areas appears to be related to a lesser effect from convectiveorographic storms in the Davis County area. Whether this difference on the two areas is primarily due to the greater distance of the Davis County area from the Gulf of Mexico, to a lesser frequency of favorable circulation, or to more intervening mountain barriers that impede the moist southerly flow, is not evident. Apparently the semimonsoon circulation that develops over the southwestern United States and makes July one of the wettest months of the year in that region does not affect the Davis County area. 
Table 4.--Average depth of precipitation, in inches, and average number of storms by month and precipitation zone

\begin{tabular}{|c|c|c|c|c|c|c|}
\hline & : & & : & : & : & \\
\hline & : & June & July & August & September & Average \\
\hline Zone & : & $\begin{aligned}: \text { No. of } \\
\text { Depth: storms }\end{aligned}$ & $\begin{array}{l}: \text { No. of : } \\
\text { :Depth: storms: }\end{array}$ & $\begin{array}{r}\text { No. of: } \\
\text { Depth: storms: }\end{array}$ & $\begin{array}{r}\text { No. of: } \\
\text { Depth: storms: }\end{array}$ & $\begin{array}{r}\text { : No. of } \\
\text { Depth: storms }\end{array}$ \\
\hline
\end{tabular}

DAVIS COUNTY EXPERIMENTAL WATERSHED

$\begin{array}{rrrrrrrrrrr}1 & 1.36 & 7.3 & .34 & 2.0 & 1.07 & 4.7 & .76 & 4.4 & .88 & 4.6 \\ 2 & 1.94 & 5.5 & .63 & 2.4 & 1.21 & 4.1 & 1.28 & 4.0 & 1.26 & 4.0 \\ 3 & 1.19 & 4.7 & .50 & 3.1 & 1.15 & 4.8 & 1.04 & 4.9 & .97 & 4.4 \\ 4 & 1.35 & 5.4 & .61 & 3.6 & 1.10 & 4.9 & .92 & 4.6 & 1.00 & 4.6 \\ \text { Average } & 1.46 & 5.7 & .52 & 2.8 & 1.13 & 4.6 & 1.00 & 4.5 & 1.03 & 4.4\end{array}$

GREAT BASIN EXPERIMENTAL AREA

\begin{tabular}{rrrrrrrrrrr}
1 & 0.60 & 7.7 & 0.59 & 6.4 & 0.73 & 8.6 & 0.79 & 6.4 & 0.68 & 7.3 \\
2 & 1.53 & 11.3 & 1.01 & 8.2 & 1.15 & 9.3 & .93 & 7.3 & 1.16 & 9.0 \\
3 & 1.30 & 9.4 & 1.41 & 11.4 & 1.62 & 13.2 & 1.38 & 10.3 & 1.43 & 11.1 \\
4 & 2.47 & 11.0 & 1.41 & 10.4 & 1.48 & 12.3 & .98 & 8.0 & 1.58 & 10.4 \\
\multirow{2}{*}{ Average } & 1.48 & 9.8 & 1.10 & 9.1 & 1.24 & 10.8 & 1.02 & 8.0 & 1.21 & 9.4 \\
\hline
\end{tabular}

\section{Storm Occurrence by Hour}

On the average, the Great Basin area receives more than twice as many storms during the period June-September than does the Davis County area (table 4).

Between the two areas, differences in hour of storm occurrence are much more striking than are zonal differences (figures 5,6 ). The inset in each of figures 5 and 6 is a schematic showing the distribution of storms by hour; in each, midnight is adjusted to zero. The insets cannot be used to derive figures 5 or 6 .

The curve for the Great Basin area is of the S-type, while that for the Davis County area is more linear--slightly concave upward. Thus, only 13 percent of the storms in the Great Basin area occur before 0600 hours, 45 percent before 1200 hours, and 84 percent before 1800 hours. On the Davis County area, 22 percent occur before 0600 hours, 45 percent before 1200 hours, and 72 percent before 1800 hours. In general, the pattern of storm occurrence in the Great Basin area conforms to the popular concept that most of the storms occur between 1000 and 1800 hours, peaking at about 1500 hours. However, the pattern in the Davis County area does not; it is more nearly uniform. There is a slight but steady increase in storm occurrence up until 2000 hours followed by a sharp decrease up until midnight. These differences in storm occurrence are probably associated with the principal source of summer moisture and atmospheric instability mechanisms. In the Great Basin area, thermal convection is the principal source of thunderstorms and the Gulf of Mexico is the chief source of moisture. In the Davis County area, two 


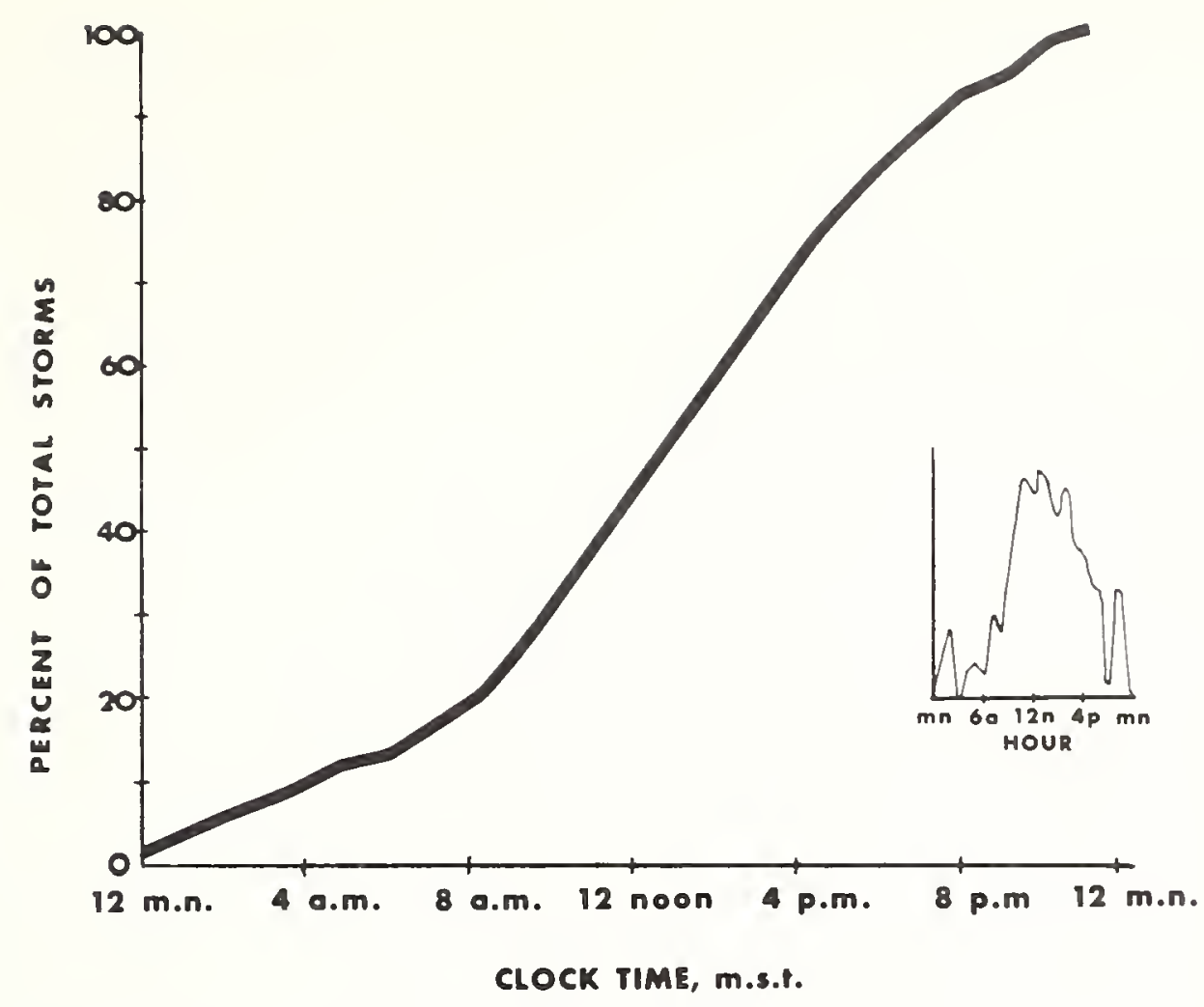

Figure 5.--Mass curve of accumulated percent of total storms by hour of storm beginning, for precipitation Zone 3 of the Great Basin Experimental Area. The inset is a schematic showing the distribution of storms by hour.

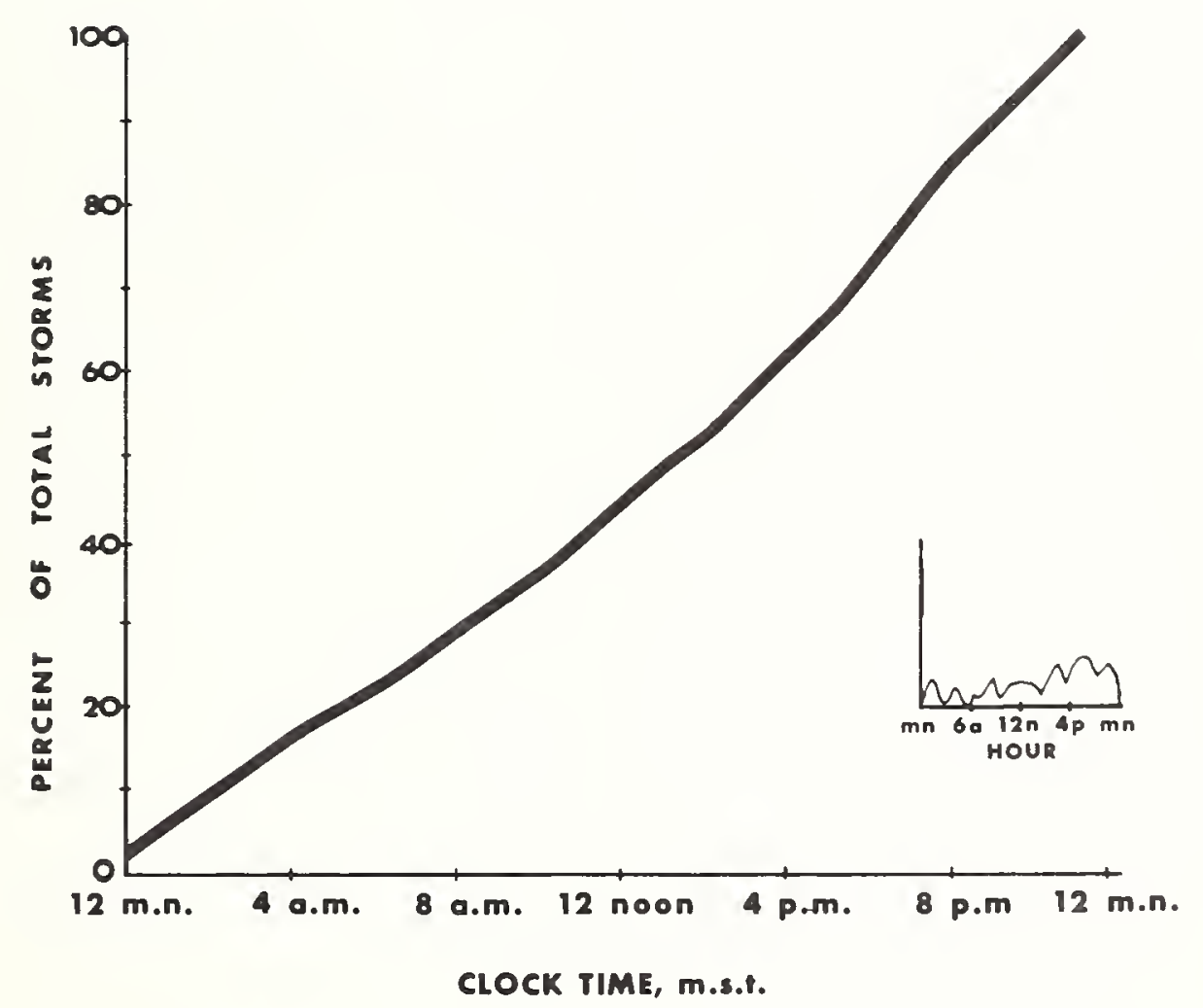

Figure 6.--Mass curve of accumulated percent of total storms by hour of storm beginning, for precipitation Zone 3 of the Davis County Experimental Watershed. The inset is a schematic showing the distribution of storms by hour. 
sources of moisture probably exist--the summer-circulation pattern that pulls moisture northward from the Gulf of Mexico and the weak cold fronts that move inland from the Pacific Ocean. These weak fronts are often of the underrunning type and trigger frontal showers and thunderstorms. The arrival of these cold fronts is independent of time. Therefore, the curve for the Davis County area does not peak markedly in the early afternoon. However, thermal convection is a common occurrence here, and this mechanism increases the occurrence of afternoon and evening thunderstorms. Weak summer cold fronts often pass to the north of the Great Basin area.

\section{Storm Occurrence by Storm Duration}

Unlike the storm-occurrence-by-hour data, these data show only minor differences between study areas, but rather marked differences between elevations. Figures 7 and 8 are mass curves of accumulated percent of total storms by storm duration for Zones 1 and 4 of the Davis County area, respectively. The curves for each zone of the Davis County area are typical of those for the Great Basin area. Figures 7 and 8 are the two extremes of the Davis County area.

As elevation increases from 4,350 feet in Zone 1 to 8,760 feet in Zone 4, the storms become notably shorter. Thus, in Zone 1, 25 percent of the storms last less than 70 minutes, 50 percent less than 135 minutes, and 75 percent less than 255 minutes. Thirteen percent of the storms exceed 6 hours in length. In Zone 4, 25 percent last less than 55 minutes, 50 percent less than 100 minutes, and 75 percent less than 155 minutes. Only 4 percent exceed 6 hours in length.

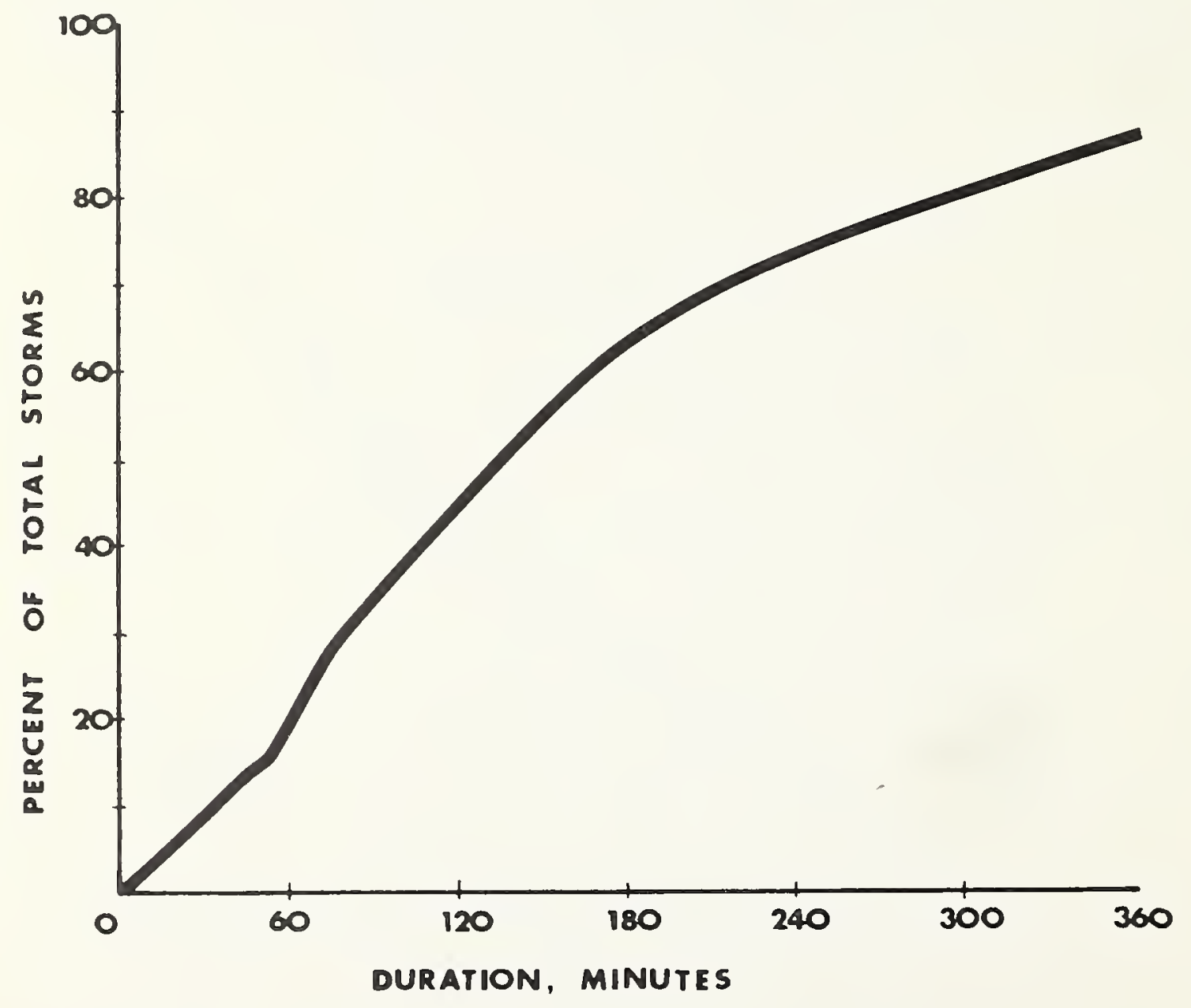

Eigure 7.--Mass curve of accumulated percent of total storms by storm duration for. precipitation Zone 1 of the Davis County Experimental Watershed. 


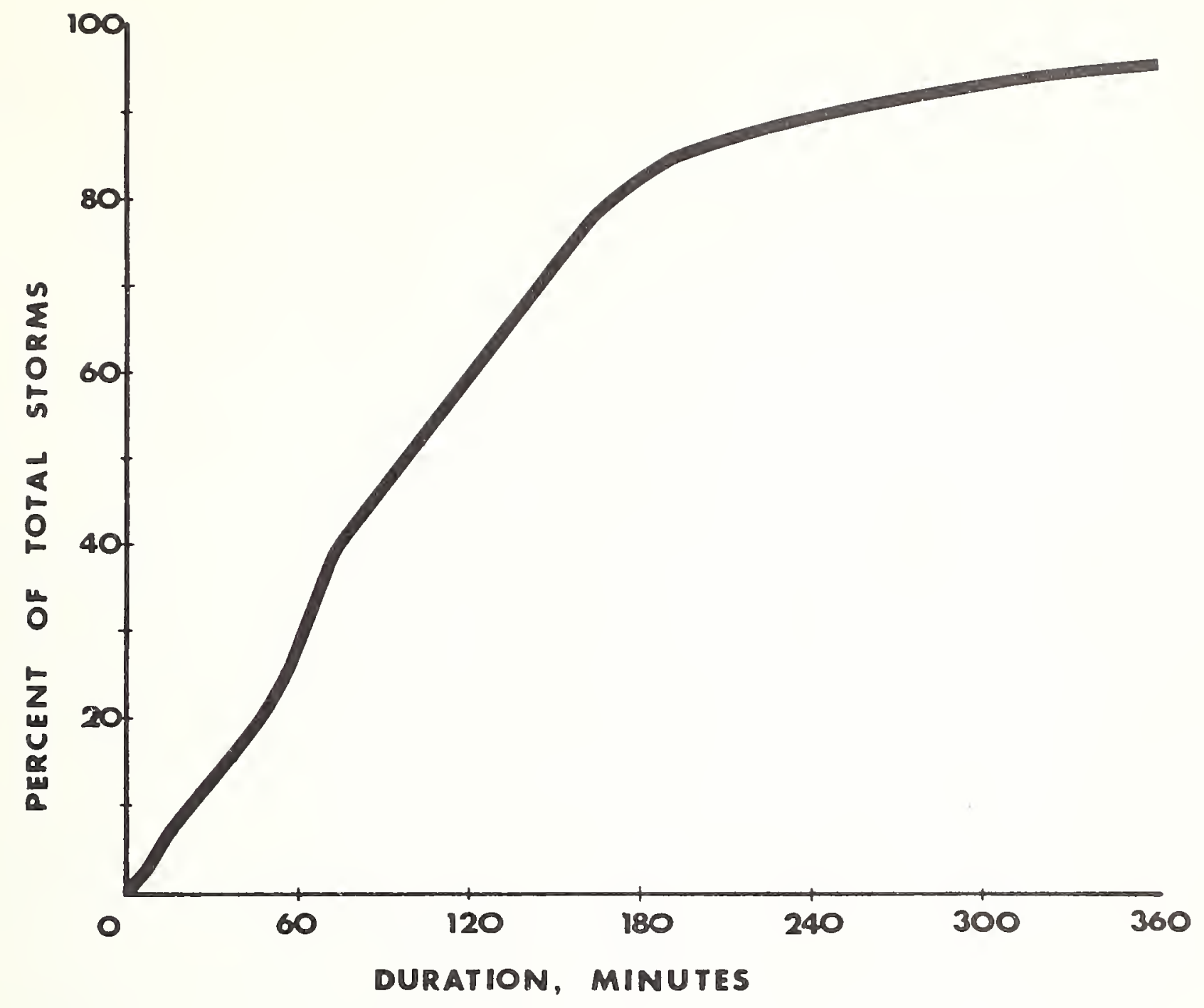

Figure 8.--Mass curve of accumulated percent of total storms by storm duration for precipitation Zone 4 of the Davis County Experimental Watershed. 


\title{
DISCUSSION
}

In general, the mountain-valley intensity relationships stated by Brancato (1942) hold true for these data. He stated:

\begin{abstract}
With regard to variation of thunderstorm rainfall with elevation...over a long period of time a station located at a lower elevation is likely to experience the most intense thunderstorm.
\end{abstract}

Dorroh (1946) also substantiates this hypothesis. However, the maximum expected rainfall intensities in the aspen-fir type are somewhat lower than those expected at either higher or lower elevations.

Plant cover destruction resulting in active flood and sediment source areas has occurred prevalently on high-elevation herbaceous sites that lie above the aspen-fir type, and was due primarily to sumer grazing overuse by livestock. Our data show that the rainfall intensities expected to occur on such sites are quite substantial.

Some of the rainfall intensities that can be expected to occur probably will be greater than the infiltration capacities of some sites, particularly those in poor hydrologic condition. Hence, overland flow is almost a certainty. Fortunately, management practices on mountain watersheds can drastically alter runoff volumes and flood peaks. This has been amply and convincingly demonstrated on the Davis County Experimental Watershed (Bailey et al. 1934 and Bailey et al. 1947). On both study areas in the middle 1930's, severe mud-rock floods were generated by storm events with a recurrence interval of only 15 years. Since that time, both vegetal and mechanical rehabilitation measures have resulted in the satisfactory disposition of storm rains of equal or greater magnitude. 
Fortunately, the greatest annual rainfall intensities can be expected to fall on the oakbrush type. Historically, flood source areas have not existed in this vegetal type. However, vegetal conversion as a means of increasing water yields from the oakbrush type has been considered. The potential hydrometeorological implications of such conversions are clear--the resulting vegetal type should be able to handle storm rainfall of high intensity without producing serious flood concentrations or soil erosion. Regardless, urban encroachment and the paving of areas within the oakbrush type can be expected to produce localized flooding.

Depth-duration curves suggest that the longer the storm, the greater the runoff. Osborn (1964) has pointed out that the use of depth-duration data can result in misleading runoff values. He reported that, in the semiarid southwest rangeland, major runoff events are often the result of short-lived, high-intensity convective storms. Osborn's conclusion is generally applicable to our study areas. Major amounts of summer runoff will usually come from storms of medium duration, i.e., 2 to 6 hours, with short periods of high-intensity rainfall bursts.

Apparently, no firm relationship exists between summer precipitation on the lowest and on the highest zones. Clyde (1931) was unable to establish a relationship between precipitation in the valleys with that in the mountains. The long term averages of monthly depth show that the ratio between highest and lowest zones varies between 1.2 and 4.1. But in any given year, these ratios may be quite different. Nonetheless, there is a definite trend toward greater average monthly depths with increasing elevation. There are no indications that precipitation depth decreases above a certain altitude.

Although the mountain-valley intensity relationships tended to follow Brancato's (1942) thesis that the lower lying stations receive the most intense rainfall, our data do not support his contention concerning the amount of rainfall. He stated:

Three to four times as many thunderstorms occurred on the middle and upper windward slopes of the mountains as on the relatively flat and lower portions of the basin. However, contrary to published and popular accounts, the thunderstorms produced the greatest amount of precipitation at the lower elevations and not on the mountain slopes. The most favorable condition for the production of heavy rain is the presence of an air mass with a sufficient amount of available energy and the greatest possible amount of moisture. Orographic lifting is very effective as a mechanism to release the latent energy in an air mass, but as the air is lifted over progressively higher terrain, the total amount of available precipitable water above any given area becomes progressively smaller.

Two assumptions upon which Brancato bases his thesis might be questioned. One is the assumption that the amount of precipitable water in an airmass becomes significantly less as it is forced over a single mountain crest. It is not likely that the total precipitable water changes very much on adjacent precipitation zones. Significant diminution of precipitable water requires the passage of an airmass over substantial sections of terrain. Another is the assumption that orographic lifting is the dominant mechanism triggering storms. Orographic effects may well contribute to summer shower activity, but the local daytime slope heating and induced upslope breezes are probably more important. Cold fronts and upper troughs may also contribute to some of the storms, especially early and late in the season. These may act in conjunction with daytime surface heating and orographic lifting.

The relation between elevation and number of storms is similar to that between elevation and average monthly rainfall depth. The ratio between the number of storm occurrences at the highest zones and at the lowest zones varies between 0.7 and 1.6. 
Table 5.--The ranges of 60-minute rainfall intensities, in inches per hour, for the 10-and 50-year

recurrence intervals by regions

\begin{tabular}{|c|c|c|c|c|}
\hline Region & $:$ & 10 years & $\begin{array}{l}: \\
:\end{array}$ & 50 years \\
\hline Central \& southern Idaho & & $0.22-0.45$ & & $0.38-0.77$ \\
\hline Northern Utah & & $0.37-0.86$ & & $0.96-2.20$ \\
\hline Central Utah & & $0.62-0.86$ & & $0.98-1.20$ \\
\hline Southern Utah \& & & & & \\
\hline northern Arizona & & $1.11-1.50$ & & $1.69-2.00$ \\
\hline Southern Arizona & & $1.61-1.99$ & & $2.22-2.60$ \\
\hline
\end{tabular}

What is the areal applicability of the intensity data? In addition to the information presented here, data are available for 41 additional intensity gages located in New Mexico, Arizona, Utah, and Idaho. The additional data include intensity-frequency information for the 60-minute durations (table 5).

The trend toward greater intensities is inescapable if one examines the hourly data at the most northern gages, which are in central Idaho, and then progressively moves to the more southerly stations in southeastern Idaho; northern, central, and southern Utah; and northern and southern Arizona. Some anomalies are present, but this is expected since these stations are grouped irrespectively of elevation, physiography, and source of summer moisture. For any given recurrence interval, our data (figs. 3,4) probably underestimate the 60-minute rainfall intensities for stations in southern Utah and Arizona and overestimate those for southern and central Idaho. This rel tionship is expected to hold for all durations from about 30 minutes to 24 hours.

Evidence that rainfall intensities in all of these areas may be reasonably comparable for durations shorter than 30 minutes exists in maximum observed 2 -minute intensities for selected stations in Idaho, Utah, and Arizona as follow: Reynolds Creek, Idaho, 17.08 inches per hour; Oaks Climatic Station, Utah, 14.40 inches per hour; and Tombstone, Arizona, 18.21 inches per hour. The maximum differences in these intensities only amount to 0.13 -inch depth in 2 minutes.

Kidd (1964), working in south-central Idaho, reported the 15-minute, 4-year return period intensity as 3 inches per hour. His period of record was only 5 years. This is about an inch per hour greater than would be expected in northern and central Utah.

Keppel and Fletcher (1958) reported the 20-minute, 100-year rainfall intensity as 6 inches per hour in southern Arizona. This is very close to the extrapolated 100-year value of 5.8 inches per hour for precipitation Zone 1 on the Davis County Experimental Watershed. They also reported that 80 percent of the storms lasted less than 4 hours. This compares quite favorably with our findings.

The transposition of these data to other areas should be approached cautiously. However, for low-risk hydrologic design problems, the data for durations less than 30 minutes are probably representative of many windward mountain slopes throughout southern Idaho, eastern Nevada, Utah, and Arizona. At durations of 30 minutes and greater, rainfall intensities reported here are probably too high for the northern part of this region and too low for the southern part. 


\section{LITERATURE CITED}

Bailey, Reed W., C. L. Forsling, and R. J. Becraft

1934. Floods and accelerated erosion in northern Utah. USDA Misc. Pub. 196, 21 p.

G. W. Craddock, and A. R. Croft

1947. Watershed management for summer flood control in Utah. USDA Misc. Pub. 639, $24 \mathrm{p}$.

Brancato, G. N.

1942. The meteorological behavior and characteristics of thunderstorms. U.S.

Dep. Comm., Weather Bureau, Wash., D.C.

Chow, V. T.

1953. Frequency analysis of hydrologic data with special application to rainfall intensities. Univ. I11. Eng. Exp. Sta. Bul1. 414.

1964. Handbook of applied hydrology, a compendium of water resources technology, Sect. 8, p. 29. New York: McGraw-Hill Book Co.

Clyde, George D.

1931. Relationship between precipitation in valleys and on adjoining mountains in northern Utah. Mon. Weather Rev. 59:113-117. 
Croft, A. R., and R. B. Marston

1950. Summer rainfall characteristics in northern Utah. Amer. Geophys. Union Trans. $31(1): 83-95$

, and R. W. Bailey

1964. Mountain water. USDA Forest Serv., Intermountain Region, Ogden, Utah. 64 p.

Dalrymple, Tate (ed.)

1960. Flood-frequency analyses, manual of hydrology, Part 3, flood-flow techniques. U.S. Geol. Surv. Water-Supply Pap. 1943-A.

Dorroh, J. H., Jr.

1946. Certain hydrologic and climatic characteristics of the Southwest. Univ. New Mexico Pub. 1.

Hovind, E. L.

1965. Precipitation distribution around a windy mountain peak. J. Geophys. Res. $70(14): 3271-3278$.

Humphrey, R. R.

1962. Range ecology, p. 16. New York: Ronald Press Co.

Keppe1, R. V., and J. E. Fletcher

1958. Runoff from rangelands of the southwest. Paper presented orally to Soil

Conserv. Soc. Amer., Asheville, N. C.

Kidd, W. J., Jr.

1964. Probable return periods of rainstorms in central Idaho. USDA Forest Serv. Res. Note INT-28, 8 p.

Orr, Howard K.

1957. Effects of plowing and seeding on some forage production and hydrologic characteristics of a subalpine range in central Utah. USDA Forest Serv., Intermountain Forest and Range Exp. Sta. Res. Pap. 47, 23 p.

Osborn, H. B.

1964. Effect of storm duration on runoff from rangeland watersheds in the semiarid southwestern United States. Int. Assoc. Sci. Hydrol. Bull. $4: 40-47$.

Packer, P. E.

1951. An approach to watershed protection criteria. J. Forest. 49:639-744.

1963. Soil stability requirements for the Gallatin elk winter range. J. Wildife Manage. $27(3): 401-410$.

Peck, E., and M. J. Brown

1962. An approach to the development of isohyetal maps for mountainous areas.

J. Geophys. Res. $64(2): 681-694$.

Price, R., and R. B. Evans

1937. Climate of the west front of the Wasatch Plateau in central Utah. Mon. Weather Rev. 65(8):291-301.

Searcy, J. K., and C. H. Hardison

1960. Double-mass curves, manual of hydrology, Part 1, general surface-water techniques. U.S. Geol. Surv. Water-Supply Pap. 1541-B. 
Headquarters for the Intermountain Forest and Range Experiment Station are in Ogden, Utah. Field Research Work Units are maintained in:

Boise, Idaho

Bozeman, Montana (in cooperation with Mon. tana State University)

Logan, Utah (in cooperation with Utah State University)

Missoula, Montana (in cooperation with University of Montana)

Moscow, Idaho (in cooperation with the Uni. versity of Idaho)

Provo, Utah (in cooperation with Brigham Young University) 
